\title{
Transport and Hydrolysis of Antibacterial Peptide Analogues in Escherichia coli: Backbone-modified Aminoxy Peptides
}

\author{
By JOHN W. PAYNE, ${ }^{1 *} \mathrm{JOHN}$ S. MORLEY, ${ }^{2} \dagger$ PHILIP ARMITAGE $^{1}$ AND \\ GILLIAN M. PAYNE ${ }^{1}$ \\ ${ }^{1}$ Department of Botany, University of Durham, Science Laboratories, South Road, \\ Durham DHI 3LE, UK \\ ${ }^{2}$ ICI Pharmaceuticals Division, Alderley Park, Macclesfield, Cheshire SK10 4TG, UK
}

(Received 29 February 1984)

\begin{abstract}
Aminoxy analogues of di- and tripeptides in which the peptide linkage is replaced by - $\mathrm{CO}-$ NHO-, either as an L- or D-2-aminoxypropionic acid (L or D-OAla) residue, have been examined for antibacterial activity in vitro and for uptake into Escherichia coli. Isolation of analogueresistant mutants and cross-resistance tests with peptide-transport mutants indicate that all three peptide permeases can transport these backbone-modified analogues. A number of mutants with defects in particular intracellular peptidases show decreased sensitivity to a range of these analogues, allowing identification of the enzymes responsible for their cleavage and confirming that hydrolysis is essential for their toxicity. Ala-OAla is a bacteriostatic agent that inhibits nucleic acid and protein synthesis within 1 min of being added to an exponentially growing culture. In crude extracts Ala-OAla inhibits transaminase activity but only after liberation of OAla by endogenous peptidases. These antibacterial agents illustrate an approach to drug targeting in which peptide carriers are used to promote uptake of essentially impermeant toxic moieties.
\end{abstract}

\section{INTRODUCTION}

In the area of drug targeting, the 'smugglin concept' (Mathews \& Payne, 1975, 1980) is one in which drugs are incorporated into molecules that are normally transported by particular organisms, in an attempt to trick these organisms into taking up the drugs. In this context, peptides appear to be especially good molecular carriers for antimicrobial compounds (see, for example, the review of Ringrose, 1980). To date, most synthetic examples of these derivatives have been formed by attaching toxic moieties at the carboxyl terminus (Ames et al., 1973; Fickel \& Gilvarg, 1973; Atherton et al., 1979, 1980), or to the side chains of the amino acid residues (Diddens et al., 1976; Boehm et al., 1983). However, we recently described the antibacterial activity of a variety of backbone-modified analogues of small peptides and presented some preliminary evidence on their uptake (Morley et al., 1983a, b).

Here, we have studied in detail one class of backbone-modified analogue in which the normal peptide linkage (-CO-NH-) is replaced by - $\mathrm{CO}-\mathrm{NHO}-$ (aminoxy analogues). Earlier studies (Morley et al., 1983a,b) showed these to be strongly antibacterial, with analogues containing D2-aminoxypropionic acid (D-OAla) residues being more toxic than the corresponding (L-OAla) derivatives. This reports shows that these analogues can be transported by all three peptide

† Present address: Pain Relief Foundation, Walton Hospital, Rice Lane, Liverpool L9 1AE, UK.

\footnotetext{
Abbreviations: AOAA, aminoxyacetic acid; OAla and D-OAla, L- and D-2-aminoxypropionic acid, respectively; BOC, $t$-butyloxycarbonyl.
} 
permeases in Escherichia coli. We identify certain of the intracellular peptidases involved in their cleavage and confirm that this hydrolysis is required to potentiate their toxicity. Finally we describe studies into their mode of inhibition.

\section{METHODS}

Bacterial strains and growth. All strains used are described in Table 1. Bacteria were grown in minimal medium A without citrate (Davies \& Mingioli, 1950), containing $0.5 \%(\mathrm{w} / \mathrm{v})$ glucose and required amino acids at $0.5 \mathrm{mM}$, at $37^{\circ} \mathrm{C}$ with shaking in a water bath: for agar plates, $1.5 \%(\mathrm{w} / \mathrm{v})$ agar was incorporated into the above media. The peptidase-deficient strains of $E$. coli K 12 and Salmonella typhimurium were obtained from C. G. Miller and have been described before (Miller \& Schwartz, 1978; Miller \& MacKinnon, 1974; McHugh \& Miller, 1974).

The peptide-transport mutants all arose spontaneously from E. coli strain M2626 (Payne, 1968) and were selected as follows (certain have been described previously). Strain PA0112 (opp) was resistant to triornithine (Payne, 1968; Alves \& Payne, 1980). Strain PA0113 (dpp) was selected from within the inhibition zone around a paper disc containing Lys-OAla $(200 \mathrm{nmol})$ on a minimal agar plate containing $200 \mu \mathrm{M}$-Lys-Lys-Lys as lysine source ; use of the tripeptide prevents selection for opp mutants which arise at high frequency (Payne, 1980) and its presence also competitively limits uptake of Lys-OAla through the oligopeptide permease. Strain PA0114 (tpp) was selected from within the inhibition zone around a disc of Ala-L-aminoethyl phosphonic acid ( $200 \mathrm{nmol})$ (alafosfalin; Atherton et al., 1979, 1980) on a minimal agar plate supplemented with lysine. Strain PA0123 (dpp opp) was a derivative of strain PA0113 (dpp), isolated from within the inhibition zone around a disc of triornithine $(1 \mu \mathrm{mol})$. In all cases, single colony isolates were purified by streaking, and characterized by cross resistance to various other toxic peptides, ability to use di, tri- and tetralysine as sources of lysine, and direct measurements of the uptake of a number of peptides (R. A. Alves, J. W. Payne \& G. M. Payne, unpublished). Finally mutants were crossed with a collection of strains carrying $\mathrm{F}^{\prime}$ factors and the $d p p$, opp and $t p p$ mutants shown to map in the regions 8-14 $\mathrm{min}, 27-30 \mathrm{~min}$ and 84-89 $\mathrm{min}$ (R. A. Alves, J. W. Payne \& G. M. Payne, unpublished).

Peptides and peptide analogues. All peptides were obtained from Sigma, except for triornithine, which was from Miles Laboratories, Stoke Poges, UK. Aminoxy peptides were synthesized as described previously (Morley et al.,

Table 1. Bacterial strains

Strain

E. coli $\mathrm{W}$

CM103†
CM104†
CM105†
CM106†
CM89†

S. typhimurium

\begin{tabular}{|c|}
\hline $\begin{array}{l}\text { M2626 } \\
\text { PA0112 } \\
\text { PA0113 } \\
\text { PA0114 } \\
\text { PA0123 } \\
\text { PA0107 }\end{array}$ \\
\hline $\begin{array}{l}\text { CM17† } \\
\text { CM } 103 \dagger \\
\text { CM104† } \\
\text { CM } 105 \dagger \\
\text { CM } 106 \dagger \\
\text { CM } 89 \dagger\end{array}$ \\
\hline $\begin{array}{l}\text { leu-485 } \\
\text { TN271 } \\
\text { TN272 } \\
\text { TN273† } \\
\text { TN274 } \\
\text { TN215† } \\
\text { proB25 } \\
\text { TN87 }\end{array}$ \\
\hline
\end{tabular}

Genotype

\begin{tabular}{|c|}
\hline $\begin{array}{l}l y s A \text { dpp opp } \\
\text { lys } d \text { dpp opp }\end{array}$ \\
\hline $\begin{array}{l}\text { CM17 pepA11 pepBI pepQ10 } \\
\text { CM17 pepBI pepN102 pepQ10 } \\
\text { CM17 pepA11 pepN102 pepQ10 } \\
\text { CM17 pepA11 pepBI pepN102 } \\
\text { CM17 pepA11 pepBI pepN102 pepQ1 }\end{array}$ \\
\hline $\begin{array}{l}\text { leu-485 } \\
\text { leu-485 pepAI pepBI pepDI } \\
\text { leu-485 pepBI pepDI pepNIO } \\
\text { leu-485 pepAl pepDI pepN10 } \\
\text { leu-485 pepAl pepBI pepN10 } \\
\text { leu-485 pepAl pepBI pepDI pepN10 } \\
\text { proB25 } \\
\text { proB25 pepPI pepQ }\end{array}$ \\
\hline
\end{tabular}

Reference*

1

This report

This report

This report

This report

This report

2

2

2

2

2

2

3

3

3

3

3

3

4

4

* References: (1) Payne (1968); (2) Miller \& Schwartz (1978); (3) Miller \& Mackinnon (1974); (4) McHugh \& Miller (1974).

$\dagger$ Strains were found here to possess the Opp phenotype. All strains derived from CM17 are pepD because the pro lac deletion in this strain includes the pepD locus (2). 
$1983 \mathrm{~b}$ ). The systematic nomenclature for these derivatives, e.g. Ala- $\Psi(\mathrm{CO}-\mathrm{NH}-\mathrm{O})-\mathrm{Ala}$, has been replaced here by the non-standard abbreviations OAla, and D-OAla to denote, respectively L-, or D-2-aminoxypropionic acid, as discussed previously (Morley et al., 1983b).

Determination of antibacterial activity. (i) Assay of growth inhibition in liquid media. The concentration of test substance that inhibited growth by $50 \%\left(\right.$ ID $\left._{50}\right)$ was measured as follows. Solutions at concentrations of $1,2,5,10$, 15 and $20 \mu \mathrm{M}$ were prepared in minimal $\mathrm{A}$ medium and equilibrated at $37^{\circ} \mathrm{C}$, together with replicate tubes without inhibitor to act as controls. Each was then inoculated with a suspension of an exponentially growing culture of strain M2626 to give approx. $10^{7}$ bacteria $\mathrm{ml}^{-1}$. Growth was measured every hour by taking optical density readings at $660 \mathrm{~nm}$. From these growth curves the percentage inhibition at $5 \mathrm{~h}$ for each concentration was plotted on a semi-log plot and a value for ID $_{50}$ was obtained.

To test whether a compound was bacteriostatic or bacteriocidal a culture was prepared as for the ID $_{50}$ test and incubated for $3 \mathrm{~h}$ with $20 \mu \mathrm{M}$ test substance. Samples of this test culture, together with a control incubated similarly but without added inhibitor, were serially diluted and plated onto minimal agar plates and viable counts determined after allowance for any difference in the optical densities of the cultures. (ii) Agar plate assay of peptide toxicity. Inhibitory activities were determined by using a radial streak technique (Roth, 1970). Aqueous solutions of peptides were sterilized by filtration, and samples $(0 \cdot 1-1 \mu \mathrm{mol})$ were dried onto sensitivity discs (Oxoid) at the centre of minimal agar plates. Using a fine platinum wire, cultures were taken from previous growth on agar plates and streaked outwards from the sensitivity disc to the edge of the test plate. This procedure allowed up to 32 cultures to be tested per plate, thus minimizing on use of test samples and allowing improved comparison between strains. After incubation for $20 \mathrm{~h}$ at $37^{\circ} \mathrm{C}$ inhibition zones were measured by doubling the distance (mm) from the centre of the disc to the start of growth of the streak; good comparability was found between these measurements and those obtained in a standard inhibition zone test (Morley et al., 1983 b). In the radial streak test, fully resistant strains grow as 'blunt-ended' streaks right up to the disc. However, some streaks extended up to the disc but were finely tapered, these strains were classified as partially resistant. (iii) Measurement of protein and nucleic acid inhibition. Measurement of $\beta$-galactosidase activity was essentially as described by Miller (1972). 1 mM-inducer was added with or without $10 \mu \mathrm{M}$-Ala-OAla to a mid-exponential phase culture of strain M2626 growing on glycerol in place of glucose. Samples were removed periodically, treated with toluene, and $\beta$-galactosidase activity measured from the absorbance at $420 \mathrm{~nm}$ using $p$-nitrophenyl- $\beta$-D-galactopyranoside as substrate.

To measure protein synthesis, $25 \mu 110 \mathrm{~mm}-\left[{ }^{14} \mathrm{C}\right]$ leucine (approx. $4 \times 10^{6} \mathrm{c} . \mathrm{p} . \mathrm{m} . \mathrm{ml}^{-1}$ ) was added with or without $20 \mu \mathrm{M}$-Ala-OAla to $4 \mathrm{ml}$ of a mid-exponential phase culture of strain M2626 at $37^{\circ} \mathrm{C}$. Samples of $200 \mu \mathrm{l}$ were removed periodically and added to $1.2 \mathrm{ml} 10 \%(\mathrm{w} / \mathrm{v})$ trichloroacetic acid. The samples were passed through glass-fibre filters (Whatman GF/C, $25 \mathrm{~mm}$ diameter), washed with $10 \mathrm{ml} 2 \%(\mathrm{w} / \mathrm{v})$ trichloroacetic acid and added to scintillation vials together with $5 \mathrm{ml}$ micellar scintillant (NE260, Nuclear Enterprises, Beenham, UK). After overnight incubation, radioactivity was measured using a scintillation counter. Measurement of nucleic acid synthesis was exactly as above except that $25 \mu \mathrm{l}$ of $10 \mathrm{mM}-\left[{ }^{3} \mathrm{H}\right] \mathrm{adenine}$ (approx. $6 \times 10^{9}$ c.p.m. $\mathrm{ml}^{-1}$ ) or $5 \mathrm{mM}-$ $\left[{ }^{14} \mathrm{C}\right]$ uracil (approx. $2 \times 10^{7}$ c.p.m. $\mathrm{ml}^{-1}$ ) were substituted for the labelled leucine.

Determination of peptidase activity. To prepare crude cell extracts, strain M2626 was grown to mid-exponential phase, harvested by membrane filtration, resuspended in $50 \mathrm{mM}$-potassium phosphate buffer, $\mathrm{pH} 7$, to a density of about $10 \mathrm{mg}$ dry wt $\mathrm{ml}^{-1}$ and the bacteria sonicated using an MSE soniprep. Cell debris was precipitated by centrifugation for $5 \mathrm{~min}$ at $12000 \mathrm{~g}$ (Hawksley Haematocrit) and the crude cell extract either used immediately or stored at $-20^{\circ} \mathrm{C}$ until use. Peptides $(10 \mathrm{~mm})$ were incubated with crude cell extract $\left(0.5-1.7 \mathrm{mg}\right.$ protein $\left.\mathrm{ml}^{-1}\right)$ at $37^{\circ} \mathrm{C}$ in $20 \mathrm{~mm}$-potassium phosphate buffer, $\mathrm{pH} 7$, containing either $1 \mathrm{~mm}$-cobaltous sulphate or $1 \mathrm{~mm}$ manganous chloride. Samples were removed periodically and either spotted immediately onto a cellulose thin layer (MN 300, Macherey Nagel \& Co.) or frozen in liquid air, lyophilized, the residues redissolved in one-third the volume of $70 \%$ ethanol and $1 \mu \mathrm{l}$ spotted onto a cellulose thin layer. Plates were run in $n$-butanol/acetic acid/ water/pyridine $(75: 15: 60: 50$, by vol.) for $4-5 \mathrm{~h}$ and developed with ninhydrin. Rates of hydrolysis were determined by reference to controls containing known amounts of substrates and cleavage products. The activity present in a commercial porcine intestinal peptidase (17 units $\mathrm{g}^{-1}$, Sigma) was measured as above using the peptidase at $2.5 \mathrm{mg} \mathrm{ml}^{-1}$.

Measurement of transaminase activity. The contents of an assay vial (Transaminase assay kit No. 55-UV, Sigma) was dissolved in $15.75 \mathrm{ml} \mathrm{H} \mathrm{H}_{2} \mathrm{O}$, and $980 \mu \mathrm{l}$ were added to a cuvette in a Gilford Model 2000 recording spectrophotometer. A sample of $20 \mu \mathrm{l}$ of a crude cell extract of strain M2626 (0.4 mg protein $\left.\mathrm{ml}^{-1}\right)$ was added, and the absorbance at $340 \mathrm{~nm}$ measured continuously for up to $3 \mathrm{~min}$ to determine an initial rate of reaction. 1-10 $\mu \mathrm{l}$ 50 mM-aminoxyacetic acid (Sigma) or other test substrate (see Results) was added, and the reaction monitored for up to $8 \mathrm{~min}$, which was time for the reaction to become inhibited and for a new steady state to be reached.

Materials. $\left[2{ }^{14} \mathrm{C}\right]$ Uracil $\left(60 \mathrm{mCi} \mathrm{mmol}^{-1}, 2 \cdot 2 \mathrm{GBq} \mathrm{mmol}^{-1}\right)$, [U-14 C]leucine $\left(25 \mathrm{mCi} \mathrm{mmol}^{-1}, 925 \mathrm{MBq}\right.$ $\left.\mathrm{mmol}^{-1}\right)$, and $\left[{ }^{3} \mathrm{H}\right]$ adenine $\left(20 \mathrm{Ci} \mathrm{mmol}^{-1}, 740 \mathrm{GBq} \mathrm{mmol}^{-1}\right)$, were obtained from Amersham International. Ala-L-aminoethyl phosphonic acid (alafosfalin) and Ala-Ala-L-aminoethyl phosphonic acid were gifts from Roche Products Ltd (Welwyn Garden City, UK). 
Table 2. Antibacterial activity of aminoxypeptides against wild-type and peptide-transport mutants of E. coli

\begin{tabular}{|c|c|c|c|c|c|c|c|}
\hline \multirow[b]{2}{*}{ Type } & \multirow[b]{2}{*}{$\mathbf{X}$} & \multirow{2}{*}{$\begin{array}{l}\text { Amount of } \\
\text { peptide used } \\
(\mu \mathrm{mol})\end{array}$} & \multicolumn{5}{|c|}{ Inhibitory activity* } \\
\hline & & & $\begin{array}{c}\text { M2626 } \\
\text { WT }\end{array}$ & $\begin{array}{c}\text { PA0112 } \\
\text { opp }\end{array}$ & $\begin{array}{c}\text { PA0113 } \\
d p p\end{array}$ & $\begin{array}{c}\text { PA0114 } \\
t p p\end{array}$ & $\begin{array}{l}\text { PA0123 } \\
\text { dpp opp }\end{array}$ \\
\hline X-OAla & $\begin{array}{l}\text { Ala } \\
\text { Val } \\
\text { Lys } \\
\text { Pro } \\
\text { Asp }\end{array}$ & $\begin{array}{l}0 \cdot 2 \\
0 \cdot 2 \\
0 \cdot 2 \\
1 \cdot 0 \\
1 \cdot 0\end{array}$ & $\begin{array}{l}30 \\
23 \\
22 \\
30 \\
22\end{array}$ & $\begin{array}{l}26 \\
27 \\
18 \\
26 \\
20\end{array}$ & $\begin{array}{l}30 \\
27 \\
26 \\
20 \\
19\end{array}$ & $\begin{array}{c}40 \\
30 \\
28 \\
\text { R } \\
22\end{array}$ & $\begin{array}{l}\text { PR } \\
18 \\
\text { R } \\
\text { R } \\
\text { R }\end{array}$ \\
\hline X-D-OAla & $\begin{array}{l}\text { Ala } \\
\text { Val }\end{array}$ & $\begin{array}{l}0 \cdot 2 \\
0 \cdot 2\end{array}$ & $\begin{array}{l}36 \\
30\end{array}$ & $\begin{array}{l}34 \\
34\end{array}$ & $\begin{array}{l}16 \\
23\end{array}$ & $\begin{array}{l}34 \\
30\end{array}$ & $\begin{array}{l}14 \\
22\end{array}$ \\
\hline $\mathrm{X}$-OAla- $\mathrm{NH}_{2}$ & $\begin{array}{l}\text { Ala } \\
\text { Val }\end{array}$ & $\begin{array}{l}1.0 \\
0.2\end{array}$ & $\begin{array}{l}26 \\
16\end{array}$ & $\begin{array}{l}22 \\
\text { PR }\end{array}$ & $\begin{array}{l}\text { PR } \\
16\end{array}$ & $\begin{array}{l}20 \\
17\end{array}$ & $\begin{array}{l}\mathbf{R} \\
\mathbf{R}\end{array}$ \\
\hline $\mathrm{X}$-D-OAla-NH ${ }_{2}$ & Ala & $1 \cdot 0$ & PR & $\mathbf{P R}$ & PR & PR & $\mathbf{R}$ \\
\hline X-Ala-OAla & $\begin{array}{r}\text { Ala } \\
\text { Val } \\
\text { Lys } \\
\text { Asp } \\
\text { Me-Ala } \\
\text { BOC-Pro }\end{array}$ & $\begin{array}{l}1.0 \\
0.2 \\
1.0 \\
0.2 \\
0.2 \\
0.2\end{array}$ & $\begin{array}{l}13 \\
24 \\
21 \\
13 \\
24 \\
16\end{array}$ & $\begin{array}{c}\text { R } \\
14 \\
\text { R } \\
\text { PR } \\
\text { R } \\
\text { R }\end{array}$ & $\begin{array}{l}18 \\
28 \\
26 \\
14 \\
32 \\
14\end{array}$ & $\begin{array}{l}18 \\
30 \\
26 \\
17 \\
\text { PR } \\
13\end{array}$ & $\begin{array}{c}\text { R } \\
14 \\
\text { R } \\
\text { PR } \\
\text { R } \\
\text { R }\end{array}$ \\
\hline X-Ala-D-OAla & $\begin{array}{l}\text { Ala } \\
\text { Pro }\end{array}$ & $\begin{array}{l}0.2 \\
0.2\end{array}$ & $\begin{array}{l}26 \\
29\end{array}$ & $\begin{array}{l}18 \\
\mathrm{R}\end{array}$ & $\begin{array}{l}24 \\
36\end{array}$ & $\begin{array}{l}27 \\
37\end{array}$ & $\begin{array}{l}20 \\
\mathrm{R}\end{array}$ \\
\hline X-OLeu & Ala & $0 \cdot 2$ & 20 & 16 & 18 & 23 & PR \\
\hline
\end{tabular}

* Diameter of inhibition zone $(\mathrm{mm})$ measured in a radial streak test.

Abbreviations: WT, wild-type; $R$ and PR are resistant and partially resistant, respectively (see Methods).

\section{RESULTS}

Transport of aminoxy peptide analogues via peptide permeases

In a previous study (Morley $e t$ al., 1983b) we presented evidence that tripeptides in which 2-aminoxypropionic acid (O-Ala) was either the central or $\mathrm{C}$-terminal residue were transported via the oligopeptide permease. This conclusion was based on the observation that strains selected as resistant to the toxic peptide triornithine and shown to carry a mutation at the oligopeptide permease locus at $27 \mathrm{~min}$ showed cross-resistance to the tripeptide aminoxy analogues. Similarly, by using resistance to Ala-OAla or to Ala-Ala-OAla as selection procedures, we obtained mutants that were cross-resistant to other toxic peptides and showed decreased uptake of a range of normal $\alpha$-linked di- and tripeptides (Alves \& Payne, 1980; R. A. Alves, G. M. Payne \& J. W. Payne, unpublished results). Here we have extended these studies to show that each of the three peptide permeases in $E$. coli can transport peptide analogues containing an aminoxy residue.

Thus, the parent strain M2626 is variably sensitive to a range of di- and tripeptide analogues containing L- or D-OAla residues (Table 2). The observed changes in sensitivity resulting from alterations in the $N$-terminal amino acid residues complement and extend the findings on side chain specificity made earlier with other strains of $E$. coli (Morley et al., 1983b) and in addition, the earlier observation that D-OAla analogues are relatively more toxic than the L-OAla forms is confirmed.

The oligopeptide-permease mutant, strain PA0112 (opp), selected as resistant to triornithine, shows extensive cross resistance to all the tripeptide analogues tested, irrespective of their $\mathrm{N}$ terminal residue. In more extensive sensitivity tests, tripeptide analogues with an N-terminal prolyl, and, to a lesser extent, lysyl, were found to be accumulated almost exclusively via the oligopeptide permease mapping at the opp locus, whereas for analogues with an $\mathrm{N}$-terminal valyl residue significant uptake occurred via the other oligopeptide permease mapping at the tpp locus (data not shown, and Table 2).

Dipeptides can be transported via all three peptide permeases, which has made it difficult to obtain mutants defective in the specific dipeptide permease $(d p p)$ using resistance to toxic 
dipeptides as a selection procedure (Payne, 1980). Indeed, initially when we used Ala-OAla to try and isolate such a strain, we obtained resistant strains that were double mutants carrying defects in both the $d p p$ and $o p p$ loci (R. A. Alves, G. M. Payne \& J. W. Payne, unpublished results). However, it proved possible to isolate strain PA0113 (dpp) by selecting for resistance to Lys-OAla in the presence of Lys-Lys-Lys. The latter peptide supplied the lysine requirement of the strain and, because it is transported mainly through the oligopeptide permease, it ensured maintenance of the opp locus whilst competitively preventing uptake of Lys-OAla by this system. The strain is not resistant to Lys-OAla in the absence of a competing tripeptide and only shows minor changes in sensitivity to the various dipeptide analogues. However, when this mutation is present in the double permease mutant, strain PA0123 ( $d p p o p p$ ), selected from PA0113 as resistant to triornithine, resistance to a range of dipeptide (and tripeptide) analogues is seen that is greater than with either defective permease alone. However, in this double mutant in which only the tpp locus remains intact, sensitivity is shown to analogues with valyl or alanyl $\mathrm{N}$-termini, in accord with other studies that show this third permease shows preference for such N-terminal residues (Naider \& Becker, 1975; Barak \& Gilvarg, 1975; J. W. Payne, unpublished results).

Strain PA0114 (tpp), selected as resistant to alafosfalin, showed cross resistance to Pro-OAla and to MeAla-Ala-OAla but because of its normally minor role in peptide accumulation, it did not show general cross-resistance. However, when a mutation in tpp was introduced into a mutant strain already defective in the $d p p$ and $o p p$ loci then this produced complete resistance to all aminoxy peptides and failure to transport any tested peptide (R. A. Alves, G. M. Payne \& J. W. Payne, unpublished results).

These results indicate that none of the three peptide permeases of $E$. coli has absolute specificity for the normal $\alpha$-peptide linkage, and that analogues in which the backbone has been extended by insertion of an oxygen atom are recognized as substrates. Furthermore, D-residues are readily absorbed when present in these analogues, although normal peptides containing Dresidues in similar positions are not transported to any significant extent (Payne, 1980).

\section{Hydrolysis of aminoxypeptides: studies with peptidase mutants}

In the initial studies on these aminoxypeptide antibiotics (Morley et al., 1983b) it had been noted that they were quite rapidly hydrolysed after being transported into $E$. coli and that the released normal amino acid residues underwent exodus, although no evidence for efflux of the aminoxy moieties was obtained. This pattern was true even for analogues containing D-aminoxy residues. It became of interest to try and identify the enzyme(s) responsible for hydrolysing the aminoxypeptide bond, especially in view of reports in the literature that such linkages are particularly resistant to hydrolysis by various mammalian peptidohydrolases (Briggs \& Morley, 1979; Kisfaludy et al., 1971, 1972). Accordingly, we have studied further the bacterial cleavage of these analogues using two approaches. Firstly, using a collection of peptidase-deficient mutants to seek any correlation between sensitivity of a strain and its complement of peptidases, and secondly, direct assays for rates of cleavage using crude cell extracts.

A series of peptidase mutants of $E$. coli K12 has been described by Miller \& Schwartz (1978), and their genotypes are listed in Table 1 . The parent strain was sensitive to a range of analogues, with those containing D-OAla being more inhibitory than the corresponding L-OAla analogue (Table 3), as had been found with other strains (see above, and Morley et al., 1983 b). However, each of the peptidase mutants showed some degree of resistance to one or more of the analogues (Table 3). Thus, strain CM103 (pepA pepB pepQ) showed significant resistance to all analogues and was completely resistant to Val-D-OAla, Val-OAla $\mathrm{NH}_{2}$ and Val-Ala-OAla. It may be immediately concluded that in order to be toxic the peptide analogues must be cleaved and that one or more of the peptidases encoded by the pepA, pepB and pep $Q$ loci are able to carry out this hydrolysis in a wild-type strain. However, there are other peptidases present in addition to those considered here (see below and Miller \& Schwartz, 1978; Hermsdorf \& Simmonds, 1980). With strain CM104 (pepN pepB pepQ) the sensitivity pattern was very similar to that of the wild-type strain. It may be concluded, therefore, that peptidase $A$ (an aminopeptidase encoded by pep $A$ ) (Miller \& Schwartz, 1978; Miller \& McKinnon, 1974; Hermsdorf \& Simmonds, 1980) is 
Table 3. Antibacterial activity of aminoxypeptides and valyl peptides against peptidase mutants of $E$. coli $\mathrm{K} 12$

Abbreviated descriptions of the absent peptidase activity are given. All strains are also pepD; see Table 1 for full genotype.

\begin{tabular}{|c|c|c|c|c|c|c|c|}
\hline \multirow[b]{2}{*}{ Type } & \multirow[b]{2}{*}{$\mathbf{X}$} & \multicolumn{6}{|c|}{ Inhibitory activity* } \\
\hline & & $\begin{array}{c}\text { CM17 } \\
\text { WT }\end{array}$ & $\begin{array}{c}\text { CM103 } \\
\operatorname{pep}(A, B, Q)\end{array}$ & $\begin{array}{c}\text { CM104 } \\
\operatorname{pep}(B, N, Q)\end{array}$ & $\begin{array}{c}\text { CM105 } \\
\operatorname{pep}(A, N, Q)\end{array}$ & $\begin{array}{c}\text { CM106 } \\
\operatorname{pep}(A, B, N)\end{array}$ & $\begin{array}{c}\text { СМ } 89 \\
\operatorname{pep}(A, B, N, Q)\end{array}$ \\
\hline X-OAla & $\begin{array}{l}\text { Ala } \\
\text { Val } \\
\text { Lys }\end{array}$ & $\begin{array}{l}40 \\
36 \\
33\end{array}$ & $\begin{array}{l}34 \\
19 \\
17\end{array}$ & $\begin{array}{l}46 \\
38 \\
34\end{array}$ & $\begin{array}{l}28 \\
31 \\
\mathbf{R}\end{array}$ & $\begin{array}{l}\mathbf{R} \\
\mathbf{R} \\
\mathbf{R}\end{array}$ & $\begin{array}{l}\mathbf{R} \\
\mathbf{R} \\
\mathbf{R}\end{array}$ \\
\hline X-D-OAla & $\begin{array}{l}\text { Ala } \\
\text { Val }\end{array}$ & $\begin{array}{l}46 \\
53\end{array}$ & $\begin{array}{c}31 \\
\text { R }\end{array}$ & $\begin{array}{l}49 \\
47\end{array}$ & $\begin{array}{l}36 \\
36\end{array}$ & $\begin{array}{l}\mathbf{R} \\
\mathbf{R}\end{array}$ & $\begin{array}{l}\mathbf{R} \\
\mathbf{R}\end{array}$ \\
\hline $\begin{array}{l}\text { X-OAla-NH } \\
\text { X-Ala-OAla }\end{array}$ & $\begin{array}{l}\text { Val } \\
\text { Ala } \\
\text { Val }\end{array}$ & $\begin{array}{l}22 \\
\mathbf{R} \\
21\end{array}$ & $\begin{array}{l}\mathbf{R} \\
\mathbf{R} \\
\mathbf{R}\end{array}$ & $\begin{array}{c}25 \\
\mathbf{R} \\
25\end{array}$ & $\begin{array}{l}\mathbf{R} \\
\mathbf{R} \\
\mathbf{R}\end{array}$ & $\begin{array}{l}\mathbf{R} \\
\mathbf{R} \\
\mathbf{R}\end{array}$ & $\begin{array}{l}\mathbf{R} \\
\mathbf{R} \\
\mathbf{R}\end{array}$ \\
\hline X-Ala-D-OAla & Ala & 33 & 27 & 32 & 23 & PR & $\mathbf{R}$ \\
\hline $\begin{array}{l}\text { Val-Val-Val } \\
\text { Val-Gly-Gly }(500 \mathrm{nmol}) \\
\text { Glu-Val-Phe }(600 \mathrm{nmol}) \\
\text { Val-Gly }(600 \mathrm{nmol})\end{array}$ & & $\begin{array}{l}34 \\
35 \\
16 \\
39\end{array}$ & $\begin{array}{l}34 \\
\mathbf{R} \\
\mathbf{R} \\
\mathbf{R}\end{array}$ & $\begin{array}{l}32 \\
33 \\
16 \\
41\end{array}$ & $\begin{array}{l}17 \\
\mathbf{R} \\
\mathbf{R} \\
\mathbf{R}\end{array}$ & $\begin{array}{l}\mathbf{R} \\
\mathbf{R} \\
\mathbf{R} \\
\mathbf{R}\end{array}$ & $\begin{array}{l}\mathbf{R} \\
\mathbf{R} \\
\mathbf{R} \\
\mathbf{R}\end{array}$ \\
\hline
\end{tabular}

* Diameter of inhibition zone (mm) measured in a radial streak test using $200 \mathrm{nmol}$ of peptide, except where indicated.

Abbreviations: WT, wild-type; R and PR are resistant and partially resistant, respectively (see Methods). All these strains are defective in the oligopeptide permease (see Text for details). E. coli $\mathrm{K} 12$ is sensitive to valine and valine-containing peptides.

responsible for a major part of the analogue cleavage occurring in strains CM17 and CM104 and, additionally, that peptidase $\mathbf{N}$ (an oligopeptidase encoded by pep $N$ : Miller \& Schwartz, 1978; Miller \& McKinnon, 1974; Hermsdorf \& Simmonds, 1980) does not act to any great extent on these substrates. Strain CM105 ( $p e p A$ pepN pep $Q$ ), which possesses peptidase B activity (an aminopeptidase showing high dipeptidase activity and encoded by the pep $B$ gene; Miller \& Schwartz, 1978; Miller \& McKinnon, 1974; Hermsdorf \& Simmonds, 1980) showed a unique resistance pattern. Thus, it was specifically resistant to Lys-OAla, indicating that peptidase B is unable to cleave this peptide, in accord with earlier studies that Lys-Lys is not a substrate (Hermsdorf \& Simmonds, 1980). It also failed to cleave Val-Ala-OAla and Val-OAla $\mathrm{NH}_{2}$, judged by its resistance to these analogues, but, interestingly, compared with strain CM103 it was relatively sensitive to Val-OAla and Val-D-OAla, indicating clearly that these are prime substrates for peptidase B. Strain CM106 (pepA pepB pepN) in which only peptidase Q (a peptidase active on aminoacyl-Pro dipeptides) was present (Miller $\&$ Schwartz, 1978; McHugh \& Miller, 1974; Miller \& Green, 1983), and strain CM89 ( pepA pepB pepN pepQ), in which all of these four peptidases were absent, were both completely resistant to all the aminoxy analogues tested.

The above results clearly show that hydrolysis is an essential step in the mechanism of toxicity of these analogues and reveal that several peptidases are able to cleave the aminoxy bond. However, in one important respect these strains were unsatisfactory, in that we have found them all, including the parent strain, to be oligopeptide permease mutants; e.g. all were resistant to triornithine, Ala-Ala-OAla, Pro-Ala-OAla, and to various other toxic tripeptides, and they failed to utilize certain tripeptides known to be good substrates of this permease (data not shown). This finding is not too surprising, for this mutation has been found frequently amongst a wide range of unselected laboratory cultures (Barak \& Gilvarg, 1974; Payne, 1980; Lenny \& Margolin, 1980).

Thus, to extend this study of the role of hydrolysis in the toxic action of oligopeptide aminoxy analogues and to identify the peptidases involved we examined some peptidase mutants of $S$. typhimurium (Miller \& McKinnon, 1974; McHugh \& Miller, 1974) (Table 4). The sensitivity of 


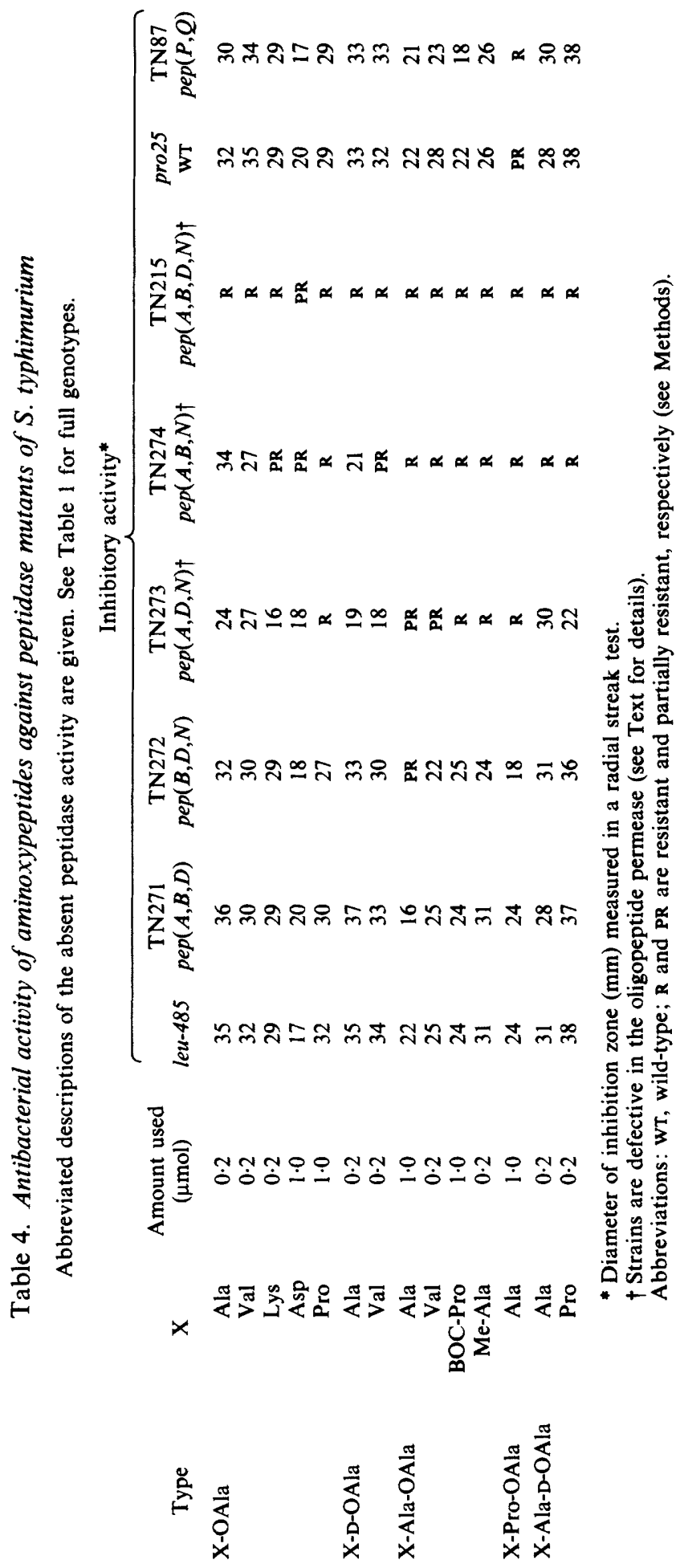


the parent strain, leu485, to a range of aminoxy analogues was similar to that found with $E$. coli and Salmonella dublin (see above and Morley et al., 1983b). The following peptides showed no toxicity against leu485 or any of the other strains: D-Ala-D-OAla, Ala-D-OAla- $\mathrm{NH}_{2}$, Ala- $\mathrm{N}$ Methyl-OAla, $N$-Methyl-Ala-OAla (each at $1 \mu \mathrm{mol}$ per disc), Asp-Ala-OAla and Ala-OLeu (Ala-L-2-aminoxy-4-methylpentanoic acid) (each at $200 \mathrm{nmol}$ per disc). Strains TN271 ( pepA pepB pepD) and TN272 ( pepB pepD pepN), although each missing three peptidases, still showed broadly similar sensitivity to the parent strain against the range of tested analogues. However, strain TN273 ( pepA pepD pepN) was considerably less sensitive to all tested dipeptide analogues, except for Asp-OAla. Strain TN273 was found to be an oligopeptide permease mutant by the same criteria as were applied above for the $E$. coli strains and this limited the studies upon tripeptides, notably, however, it was sensitive to tripeptides with C-terminal DOAla residues. Strain TN274 (pepA pepB pepN) was also found to be an oligopeptide permease mutant, but it differed from TN273 in that its different peptidase complement made it resistant to the aminoacyl-Ala-D-OAla analogues (Table 4) and also to Ala-Ala-L-aminoethyl phosphonic acid (data not shown). However, results with this mutant show that dipeptidase D (and/or a further unspecified peptidase) is able to hydrolyse Ala-OAla and Ala-D-OAla, but fails to hydrolyse the other dipeptide analogues; comparison with other strains indicates that LysOAla, Asp-OAla and Val-D-OAla can be cleaved by any of peptidases A, B or N. When the results with these two strains are compared with those for strains TN271 and TN272 it appears that neither peptidase B nor D (a broad specificity dipeptidase, Miller \& Schwartz, 1978; Hermsdorf \& Simmonds, 1980) can cleave the Pro-OAla bond whereas peptidase $\mathrm{N}$ and, to a lesser extent, peptidase A can both hydrolyse it. Strain TN215 ( pepA pepB pepD pepN) was also found to be an oligopeptide permease mutant, and yet differed from strain TN274 in being resistant to Ala-OAla and to Ala-D-OAla; it may be concluded, therefore, that these two analogues are indeed cleaved mainly by peptidase D. A further peptidase mutant, strain TN87 ( $p e p Q$ pepP), lacked activity primarily responsible for cleaving aminoacyl-Pro peptide bonds (McHugh \& Miller, 1974; Miller \& Green, 1983; Hermsdorf \& Simmonds, 1980). However, when the response of this strain was compared with that of its parent, both were of comparable sensitivity to all tested analogues.

\section{Hydrolysis of aminoxypeptides: studies with crude extracts}

The above results provide evidence for the involvement of several of the characterized peptidases of $E$. coli and $S$. typhimurium in cleavage of backbone-modified peptides containing aminoacyl-L-OAla and aminoacyl-D-OAla bonds. However, we sought to confirm this conclusion and to obtain some absolute rates of hydrolysis in vitro by direct assays for cleavage using crude extracts from parent and mutant strains. Table 5 indicates that with $E$. coli M2626 the rate of hydrolysis of Ala-OAla $\left[140 \mathrm{nmol} \mathrm{min}{ }^{-1}(\mathrm{mg} \text { protein })^{-1}\right]$ is very comparable with that found for normal dipeptides, e.g. Ala-Ala, Leu-Leu, approx. 200-800 $\mathrm{nmol} \mathrm{min}^{-1}$ (mg protein $)^{-1}$; identical rates of cleavage were found for a mutant strain PA0107 selected as being resistant to Ala-OAla and shown in separate studies to be a dpp opp transport mutant (R. A. Alves, G. M. Payne, \& J. W. Payne, unpublished results). This finding endorses the general conclusion that these aminoxy analogues need to be absorbed to be toxic (Morley et al., 1983 b).

In $S$. typhimurium, rapid cleavage of Ala-Ala-D-OAla $\left[170 \mathrm{nmol} \mathrm{min}{ }^{-1}(\mathrm{mg} \text { protein })^{-1}\right]$ was found with extracts of the wild-type strain leu485 (Table 5), hydrolysis was slightly slower [60 $\mathrm{nmol} \min ^{-1}$ (mg protein) $\left.)^{-1}\right]$ in strain TN273 (pepA pepD pepN) which was as sensitive as the wild-type (Table 4), whereas activity in strain TN274 (pepA pepD pepN) was intermediate [120 $\mathrm{nmol} \min ^{-1}(\mathrm{mg} \text { protein })^{-1}$ ], endorsing the fact that the resistance of this strain to this and other tripeptides arises from a defect in uptake via the oligopeptide permease rather than a deficiency in peptidase activity. However, when measuring activities in broken cell extracts there is always an inherent uncertainty as to how closely these reflect the activities present in vivo. Thus, with $\mathrm{N}$-methyl-Ala-Ala-OAla, which was as inhibitory as Ala-Ala-D-OAla against leu485 (Table 4), its rate of cleavage in extracts from the three strains leu485, TN273 and TN274 was less than $1 \mathrm{nmol} \mathrm{m^{-1 }}$ (mg protein) ${ }^{-1}$ (Table 5). It is uncertain, therefore, as to whether this low rate of cleavage is indeed sufficient for the observed toxicity in vivo or whether 
Table 5. Peptidase activity in crude extracts of E. coli and S. typhimurium

Source of extract

M2626 wT
M2626 wT
M2626 wT
PA0107 dpp opp
PA0107 dpp opp
leu-485 wT
leu-485 wT
leu-485 wT
TN215 pepA pepB pepD pepN
TN215 pepA pepB pepD pepN
TN215 pepA pepB pepD pepN
leu-485 WT
TN273 pepA pepD pepN
TN274 pepA pepB pepN
leu-485 wT
TN273 pepA pepD pepN
TN274 pepA pepD pepN
Intestinal
Intestinal
Intestinal

\section{Substrate}

(10 mM)

Ala-Ala
Leu-Leu
Ala-OAla
Leu-Leu
Ala-OAla
Val-Ala
Val-OAla
Val-D-OAla
Val-Ala
Val-OAla
Val-D-OAla
Ala-Ala-D-OAla
Ala-Ala-D-OAla
Ala-Ala-D-OAla
MeAla-Ala-OAla
MeAla-Ala-OAla
MeAla-Ala-OAla
Val-Ala
Val-OAla
Val-D-OAla

\author{
Supplement \\ (1 mM)
}

$\mathrm{Co}^{2+}$
$\mathrm{Co}^{2+}$
$\mathrm{Co}^{2+}$
$\mathrm{Co}^{2+}$
$\mathrm{Co}^{2+}$
$\mathrm{Co}^{2+}$
$\mathrm{Co}^{2+}$
$\mathrm{Co}^{2+}$
$\mathrm{Co}^{2+}$
$\mathrm{Co}^{2+}$
$\mathrm{Co}^{2+}$
$\mathrm{Mn}^{2+}$
$\mathrm{Mn}^{2+}$
$\mathrm{Mn}^{2+}$
$\mathrm{Mn}^{2+}$
$\mathrm{Mn}^{2+}$
$\mathrm{Mn}^{2+}$
$\mathrm{Co}^{2+}$
$\mathrm{Co}^{2+}$
$\mathrm{Co}^{2+}$

\author{
Activity \\ [nmol $\min ^{-1}$ (mg protein $\left.)^{-1}\right]$
}

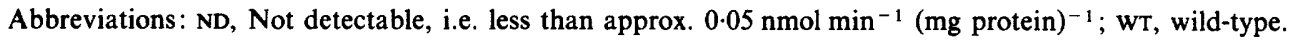

the hydrolytic activity measured in vitro is low. A similar reservation applies to the series ValAla, Val-L-OAla and Val-D-OAla, with rates of 400,1 and $3 \mathrm{nmol} \mathrm{min}^{-1}$ (mg protein) ${ }^{-1}$, respectively (Table 5); the rates for the analogues are again low, although interestingly the relative cleavage rates parallel their respective toxicities (Table 2). It was shown earlier (Morley et al., 1983 ) that the toxic analogues are taken up at rates of about $5-20 \mathrm{nmol} \mathrm{min}^{-1}$ (mg protein $)^{-1}$ so these slow hydrolysis rates may be adequate for toxicity in vivo. Significantly, however, the activity of extracts of the multiple peptidase mutant strain TN215 was indeed low, being $20 \mathrm{nmol} \mathrm{min}^{-1}$ (mg protein) ${ }^{-1}$ for Val-Ala, and undetectable for Val-L-OAla and Val-DOAla (Table 5). Finally, for comparison, we measured hydrolysis of these three peptides by a crude mixture of intestinal peptidases (Table 5). The rates were all of comparable magnitude and the D-OAla peptide was cleaved faster than its L-OAla analogue.

\section{Antibacterial activity of aminoxypeptides}

The ID $_{50}$ of Ala-OAla against strain M2626 (see Methods) was determined as $1.5 \mu \mathrm{M}$. To determine whether Ala-OAla exerted a bacteriostatic or bacteriocidal action (see Methods), strain M2626 was incubated for $3 \mathrm{~h}$ with $20 \mu \mathrm{M}$-Ala-OAla (during which time no noticeable increase in optical density occurred), and a viable count was carried out. No significant loss of viability occurred, indicating the bacteriostatic nature of the compound. When the culture was examined microscopically after the $3 \mathrm{~h}$ incubation, no differences could be seen between it and an untreated control.

\section{Inhibition of induced enzyme activity}

The influence of Ala-OAla on expression of induced $\beta$-galactosidase activity (see Methods) was detectable within $2 \mathrm{~min}$; inhibition was over $80 \%$ when measured $10 \mathrm{~min}$ after addition of inducer and Ala-OAla (data not shown).

\section{Inhibition of protein and nucleic acid synthesis}

The above experiment did not show whether the inhibition of $\beta$-galactosidase activity results from interference with the synthesis of the enzyme per se or whether protein synthesis occurs but an inactive enzyme is produced. To see if synthesis is inhibited the incorporation of $\left[{ }^{14} \mathrm{C}\right]$ leucine into trichloroacetic acid-precipitated protein was followed. Marked inhibition of protein 
synthesis was observed within several minutes and was maintained throughout the incubation period $(45 \mathrm{~min})$; at $30 \mathrm{~min}$ incorporation of radioactivity was inhibited $95 \%$. To determine if this inhibition is exercised at the level of transcription or translation, the effects upon nucleic acid synthesis were studied. Inhibition of incorporation of $\left[{ }^{3} \mathrm{H}\right]$ adenine was observed within several minutes and was maintained throughout the $45 \mathrm{~min}$ incubation; at $30 \mathrm{~min}$ incorporation of radioactivity was inhibited $90 \%$. Inhibition of $\left[{ }^{14} \mathrm{C}\right]$ uracil incorporation into mRNA was readily apparent at $1 \mathrm{~min}$ and amounted to $75 \%$ inhibition at $3 \mathrm{~min}$.

\section{Inhibition of glutamic-oxalacetic transaminase}

Transaminase activity present in a crude cell extract of M2626 was assayed in a coupled enzyme system by continuously measuring the rate of decrease in absorbance at $340 \mathrm{~nm}$ (see Methods). Aminoxyacetic acid (AOAA, an OGly analogue), a known transaminase inhibitor, was used as a standard against which to judge the activity of Ala-OAla and aminoxypropionic acid (OAla). When AOAA was added to the incubation mixture in which transamination was proceeding at a linear rate, an immediate inhibition was seen, and after a short time a new steady rate of decrease in absorbance at $340 \mathrm{~nm}$ was reached; e.g. 50, 250 and $500 \mu \mathrm{M}$-AOAA inhibited to about 70,90 and $90 \%$ within about 8,4 and $2 \mathrm{~min}$, respectively. When Ala-OAla $(0 \cdot 2-1.0 \mathrm{mM})$ was tested similarly, no inhibition was noted during the test period $(6 \mathrm{~min})$, whereas OAla behaved similarly to AOAA and was about $50 \%$ as inhibitory. However, when Ala-OAla ( $10 \mathrm{mM})$ was first incubated with crude extract $\left(0.4 \mathrm{mg}^{2}\right.$ protein $\left.\mathrm{ml}^{-1}\right)$ for $20 \mathrm{~min}$ (to permit peptidase action on the Ala-OAla) and then tested, it inhibited transamination to an extent commensurate with its content of OAla (results not shown).

\section{Effect upon alanine racemase}

The above mechanistic studies have been confined to Ala-OAla. However, in as much as analogues containing D-OAla residues are relatively more toxic it is possible that this moiety might, in addition, possess extra modes of action, of which inhibition of alanine racemase is an obvious candidate. To test for this possibility we performed standard inhibition zone tests with strain M2626 (Morley et al., 1983 b) using sensitivity discs impregnated with $200 \mathrm{nmol}$ Val-OAla or Val-D-OAla on minimal agar plates plus or minus D-alanine $(0.5 \mathrm{~mm})$. The presence of $\mathrm{D}$ alanine did not diminish the toxicity of Val-D-OAla, in fact the inhibition zones were somewhat larger for both analogues in the presence of D-alanine. Thus, as a further test, paper strips $(50 \times$ $5 \mathrm{~mm}$ ) were impregnated with $400 \mathrm{nmol}$ Val-OAla or Val-D-OAla and placed on minimal agar plates abutting at right angles similar strips containing D-alanine $(1 \mu \mathrm{mol})$; at no interacting concentration was there evidence that $D$-alanine could relieve toxicity of either peptide. As a control we showed that $\mathrm{D}$-alanine did relieve the inhibition caused by D-cycloserine (in effect a cyclic analogue of D-aminoxyalanine) that is known to inhibit alanine racemase (Ringrose, 1980).

\section{DISCUSSION}

In a previous study (Morley et al., 1983b), we showed that a range of peptides containing L- or D-2-aminoxypropionic acid residues were inhibitory towards several bacterial species. The free amino acid analogues were relatively non-toxic and preliminary evidence was presented that the peptides were acting as carriers for the impermeant toxic moities; these aminoxy peptides therefore belonged to the class of 'smugglin' antibiotics (Matthews \& Payne, 1975). Here, we sought the answers to three questions: (i) which peptide permeases are used for uptake of the aminoxy analogues; (ii) which enzyme(s) is responsible for the intracellular release of the aminoxy moiety and is such hydrolysis essential for toxicity; and (iii) what is the mechanism of toxicity?

\section{Permease specificity for aminoxy peptide uptake}

The results show that all three peptide permeases, coded by the opp, $d p p$ and tpp loci (Payne $1980,1983)$, are used by aminoxy peptides. Thus, none of these systems has absolute specificity for the normal $\alpha$-peptide backbone. However, some specificity towards $\mathrm{N}$-terminal residues can be concluded from the data shown here and previously (Morley et al., 1983b). Thus, all 
tripeptides use the opp system, which has particular specificity towards tripeptides with $\mathrm{N}$ terminal prolyl or lysyl residues whereas peptides with $\mathrm{N}$-terminal valyl residues are especially good substrates for the tpp system. A novel observation here is that although opp mutants are resistant to tripeptides with C-terminal L-OAla residues they are still relatively sensitive to AlaAla-D-OAla. This may reflect a specificity difference between the opp and tpp systems; earlier studies indicated that the opp system could handle normal $\alpha$-linked tripeptides with a C-terminal D-residue (Payne, 1980).

The toxicity of BOC-Pro-Ala-OAla (Tables 2 and 4) is of particular interest; it inhibits various strains but not opp mutants. Early studies provided evidence to indicate that peptides with an acylated N-terminus are not substrates of the peptide permeases (Payne, 1980). However, in earlier reports, it was shown that $\alpha-N$-acetyltrilysine and $\alpha-N$-acetyltrialanine could be utilized, albeit poorly, by E. coli (Losick \& Gilvarg, 1966; Deutch \& Soffer, 1978). In the latter case, evidence was presented that a periplasmic dipeptidyl carboxypeptidase cleaved the substrate to give $\alpha-N$-acetylalanine and dialanine (Deutch \& Soffer, 1978; Vimr \& Miller, 1983). Whilst this mode of cleavage could explain the toxicity of BOC-Pro-Ala-OAla it cannot explain the resistance of opp mutants, for the Ala-OAla moiety can enter via the other permeases. One possible explanation that we considered stemmed from the fact that the gene coding for dipeptidyl carboxypeptidase $(d c p)$ lies in the region 27-31 min (Deutch \& Soffer, 1978) and mutants lacking this activity are complemented by the plasmid $F^{\prime} 123$. This is the same region in which opp maps and $F^{\prime} 123$ is the plasmid we used to complement opp mutants (unpublished results). As this region is one in which deletions occur frequently (Coukell \& Yanofsky, 1971; Lenny \& Margolin, 1980) it was possible that the opp mutants studied also carried a defect in $d c p$ and it was loss of this latter activity that made them resistant to BOC-Pro-Ala-OAla. However, although in general this may remain a possibility, we find the opp mutants used here retain $d c p$ activity (unpublished results). Further studies are needed to clarify this aspect, but it appears that a re-evaluation of the ability to transport $\alpha-N$-acyl oligopeptides may be required.

A further new finding with the collection of permease mutants described here is that a defect in one permease may actually lead to increased sensitivity towards certain analogues. Although further studies of this point will be needed, including direct transport assays, it is possible that some co-ordinate regulation operates between the three permeases and loss of one activity may allow enhanced expression of another system.

\section{Peptidase action on aminoxy peptides}

It was shown earlier that $E$. coli cells rapidly hydrolyse the aminoxy analogues and the cleaved amino acid residues undergo exodus (Morley et al., 1983 b). The varied resistance patterns of the peptidase mutants of $E$. coli and $S$. typhimurium described here (Tables 3 and 4) indicate that the aminoxy analogues must be cleaved to be toxic and that this hydrolysis can be carried out by several well-characterized peptidases. Hydrolysis rates measured in vitro vary depending on the sequence of the peptide and are often faster for the D-OAla than the L-OAla analogue (Table 5); ease of hydrolysis may be a significant determinant of relative antibacterial activity.

The common occurrence of $o p p$ mutants amongst the peptidase-deficient strains reflects the particular advantage of this mutation in such a genetic background. We have found that these peptidase strains frequently show sensitivity to simple peptides that they cannot cleave (unpublished results), consequently for these strains an enriched medium, e.g. L-broth, may be toxic and will provide a strong selective pressure for growth of $o p p$ mutants. Indeed it may be that the high frequency of opp mutations (usually 1 in $10^{5}$ for M2626) is of survival value in nature if inhibitory peptides are of common occurrence.

Previous studies (Kisfaludy et al., 1971, 1972; Schon et al., 1978; Briggs \& Morley, 1979) indicated that analogues containing $\alpha$-aminoxy-2-phenylpropionic acid (OPhe) or $\alpha$-aminoxy-4methylpentanoic acid (OLeu) in peptide linkage were either not cleaved by mammalian peptidohydrolases (trypsin, chymotrypsin, leucineaminopeptidase, carboxypeptidases A and B) or showed resistance comparable with peptides substituted by D-amino acid residues. Although our results with the OAla analogues are not directly comparable with these studies, there is some indication that bacterial enzymes may be better able to hydrolyse the aminoxy peptide bond. 
Carrier molecules that are resistant to mammalian hydrolysis but are cleaved by target bacteria are an ideal design feature of synthetic smugglin antibiotics (Matthews \& Payne, 1975).

\section{Mode of antibacterial action}

The aminoxy analogues are bacteriostatic agents that function as true smugglin antibiotics, i.e. the peptide portion acts as a carrier to transport the impermeant aminoxy moiety. The OAla residue is liberated intracellularly and it is this that is the toxic species; we found no evidence that the peptide analogues per se are inhibitory. Overall, therefore, their mode of action resembles that of alafosfalin and some other natural and synthetic peptide antibiotics in so much as they require transport and hydrolysis for activity, although they do not appear to affect alanine racemase (Atherton et al., 1979; Ringrose, 1980). Following uptake and hydrolysis, AlaOAla rapidly stops mRNA and protein synthesis. In crude extracts the liberated OAla inhibits pyridoxal phosphate-dependent transaminase activity, in a manner similar to that reported previously for aminoxyacetic acid (John et al., 1978). Further studies are needed to establish whether the target of these aminoxy peptides is a pyridoxal phosphate-dependent step in mRNA synthesis.

The collaboration of Dr C. F. Hayward and A. S. Graham in the synthesis of the analogues is gratefully acknowledged. We thank Dr C. G. Miller for the peptidase mutants. Financial support to J. W. P. was provided through a grant from the Science and Engineering Research Council.

\section{REFERENCES}

Alves, R. A. \& Payne, J. W. (1980). The number and nature of the peptide-transport systems in Escherichia coli: characterization of specific transport mutants. Biochemical Society Transactions 8, 704705.

Ames, B. N., Ames, G. F. L., Yolng, J. D., Isuchiya, D. \& LeCOCQ, J. (1973). Illicit transport, the oligopeptide permease. Proceedings of the National Academy of Sciences of the United States of America 70. $456-458$.

Atherton, F. R., Hall, M. J., Hassall, C. H., LAMbert, R. W., Lloyd, W. J. \& Ringrose, P. S. (1979). Phosphonopeptides as antibacterial agents: mechanism of action of alaphosphin. Antimicrobial Agents and Chemotherapy 15, 696-705.

Atherton, F. R., Hall, M. J., Hassall, C. H., Holmes, S. W., Lambert, R. W., Lloyd, W. J. \& Ringrose, P. S. (1980). Phosphonopeptide antibacterial agents related to alafosfalin: design, synthesis and structure-activity relationships. Antimicrobial Agents and Chemotherapy 18, 897-905.

Barak, Z. \& Gillarg, C. (1974). Triornithine resistant strains of Escherichia coli: Isolation, definition and genetic studies. Journal of Biological Chemistry. 249. $143-148$

BaraK, Z. \& Gilvarg, C. (1975). Specialized peptide transport system in Escherichia coli. Journal of Bacteriology 122, 1200-1207.

Boehm. J. C., Kingsbury, W. D., Perry, D. \& Gilvarg, C. (1983). The use of cysteinyl peptides to effect portage transport of sulfhydryl-containing compounds in Escherichia coli. Journal of Biological Chemistry 258, 14850-14855.

Briggs, M. T. \& Morley, J. S. (1979). Aminoxyanalogues of aspartame and gastrin C-terminal tetrapeptide amide. Journal of the Chemical Society, Perkin 1, 2138-2143.
Coukell, M. B. \& Yanofsky, C. (1971). Influence of chromosome structure on the frequency of tonBtrp deletions in Escherichia coli. Journal of Bacteriology 105, 864-872.

Davis, B. D. \& Mingloli, E. S. (1950). Mutants of Escherichia coli requiring methionine or vitamin $\mathrm{B}_{12}$. Journal of Bacteriology 60, 17-28.

Deutch, C. E. \& SofFER, R. L. (1978). Escherichia coli mutants defective in dipeptidyl carboxypeptidase. Proceedings of the National Academy of Sciences of the United States of America 75, 5998-6001.

Diddens, H., Zahner, H., KraAs, E., Gohring, W. \& JUNG, G. (1976). On the transport of tripeptide antibiotics in bacteria. European Journal of Biochemistry 66, 11-23.

Fickel, T. E. \& Gilvarg, C. (1973). Transport of impermeant substances in Escherichia coli by way of the oligopeptide permease. Nature New Biology 241, $161-163$.

Hermsdorf, C. L. \& Simmonds, S. (1980). Role of peptidases in utilization and transport of peptides by bacteria. In Microorganisms and Nitrogen Sources, pp. 301-334. Edited by J. W. Payne. Chichester \& New York: John Wiley.

John, R. A., Charteris, A. \& Fowler, L. J. (1978). The reaction of amino-oxyacetate with pyridoxal phosphate-dependent enzymes. Biochemical Journal 171, 771-779.

Kisfaludy, L., Low, M. \& DévénYI, T. (1971). Enzymatic degradation of peptides containing $\alpha$ aminooxycarboxylic acids. Acta biochimica et biophysica Academiae scientiarum hungaricae 6, 393-403.

Kisfaludy, L., Low, M., Dancsi, L., Patthy, A., NyekI, O. \& SARKozI, M. (1972). Alfa-aminooxy acids and derivatives. In Peptides 1972, pp. 409-415. Edited by H. Hanson \& H. D. Jakubke. Amsterdam \& New York: North Holland/Elsevier. 
LENNY, A. B. \& MARgolin, P. (1980). Locations of the opp and supX genes of Salmonella typhimurium and Escherichia coli. Journal of Bacteriology 143, 747-752.

Losick, R. \& Gilvarg, C. (1966). Effect of $\alpha$ acetylation on utilization of lysine oligopeptides in Escherichia coli. Journal of Biological Chemistry 241, 2340-2346.

Matthews, D. M. \& Payne, J. W. (1975). Occurrence and biological activities of peptides. In Peptide Transport in Protein Nutrition, pp. 428-429. Edited by D. M. Matthews \& J. W. Payne. Oxford \& Amsterdam: North Holland/Elsevier.

Matthews, D. M. \& PAYNE, J. W. (1980). Transmembrane transport of small peptides. Current Topics in Membranes and Transport 14, 331-425.

MCHugh, G. L. \& Miller, C. G. (1974). Isolation and characterization of proline peptidase mutants of Salmonella typhimurium. Journal of Bacteriology 120, 364-371.

Miller, C. G. \& Green, L. (1983). Degradation of proline peptides in peptidase-deficient strains of Salmonella typhimurium. Journal of Bacteriology 153, 350-356.

Miller, C. G. \& MacKinnon, K. (1974). Peptidase mutants of Salmonella typhimurium. Journal of Bacteriology 120, 355-363.

Miller, C. G. \& Schwartz, G. (1978). Peptidase deficient mutants of Escherichia coli. Journal of Bacteriology 135, 603-611.

MilleR, J. H. (1972). Experiments in Molecular Genetics. New York: Cold Spring Harbor Laboratory.

Morley, J. S., Hennessey, T. D. \& Payne, J. W. (1983a). Backbone modified analogues of small peptides: transport and antibacterial activity. Biochemical Society Transactions 11, 798-800.
Morley, J. S., Payne, J. W. \& Hennessey, T. D. $(1983 b)$. Antibacterial activity and uptake into Escherichia coli of backbone-modified analogues of small peptides. Journal of General Microbiology 129, 3701-3708.

NAIDER, F. \& BECKER, J. M. (1975). Multiplicity of oligopeptide transport systems in Escherichia coli. Journal of Bacteriology 122, 1208-1215.

PAYNE, J. W. (1968). Oligopeptide transport in Escherichia coli: specificity with respect to side chain and distinction from dipeptide transport. Journal of Biological Chemistry 243, 3395-3403.

PAYNE, J. W. (1980). Transport and utilization of peptides by bacteria. In Microorganisms and Nitrogen Sources, pp. 211-256. Edited by J. W. Payne. Chichester \& New York: John Wiley.

Payne, J. W. (1983). Peptide transport in bacteria: methods, mutants and energy coupling. Biochemical Society Transactions 11, 794-798.

Ringrose, P. S. (1980). Peptides as antimicrobial agents. In Microorganisms and Nitrogen Sources, pp. 641-692. Edited by J. W. Payne. Chichester \& New York: John Wiley.

Roтн, J. R. (1970). Genetic techniques in studies of bacterial metabolism. Methods in Enzymology 17, 135.

Schon, I., Kisfaludy, L., Nafradi, J., Varga, L. \& VARRO, V. (1978). Pentagastrin analogs containing $\alpha$-aminooxy acids. III. Biological Studies and structure-activity relationships. Hoppe-Seyler's Zeitschrift für physiologische Chemie 359, 917-922.

Vimr, E. R. \& Miller, C. G. (1983). Dipeptidyl carboxypeptidase-deficient mutants of Salmonella typhimurium. Journal of Bacteriology 153, 1252-1258. 